\title{
English language teaching for students of management of travel and tourism
}

\author{
Jaroslav Kacetl ${ }^{1, *}$ \\ ${ }^{1}$ University of Hradec Kralove, Rokitanskeho 62, Hradec Kralove 500 03, Czech Republic
}

\begin{abstract}
English has become the lingua franca in a lot of areas, including tourism industry. The aim of this contribution was to explain the way English is taught to students of Management of Travel and Tourism at the Faculty of Informatics and Management, University of Hradec Kralove, Czech Republic. The basic teaching approaches were described, and justified. Methods of collecting as well as creating teaching materials were exemplified. The resulting syllabi should be implemented in the coming years. Prior to this implementation, the whole curriculum of Management of Travel and Tourism has to be revised as the new accreditation is due in 2019. The new approach takes into account the fact that people working in tourism need to master especially speaking and listening as they are expected to communicate with foreigners.
\end{abstract}

\section{Introduction}

The Department of Applied Linguistics, Faculty of Informatics and Management (FIM), University of Hradec Kralove, provides English language lessons for all FIM students, including those who study Management of Travel and Tourism. Management of Travel and Tourism is the most language-oriented field of study at FIM. Its students can focus either on English or German. As Semradova and Hubackova [1] summarised, language teaching to full-time students of Management of Travel and Tourism may extends to 8-10 lessons a week. Two lessons of practical language usage skills a week are compulsory, the student can also attend optional subjects focusing on realia, translating, and literature and cultural studies of the countries where English or German are spoken. Nonetheless, this contribution focuses entirely on English language teaching.

With an impending date of accreditation renewal, it is necessary to revise and possibly improve the curriculum and syllabi of all subjects taught to the students of Management of Travel and Tourism, particularly the compulsory ones, i.e. in case of English language lessons Practical English Language 1 - 4. The whole procedure is quite complicated as new syllabi as well as e-learning courses should be created. For language teachers this includes finding as well as creating relevant study materials and textbooks and all this in close cooperation with teachers from the Department of Recreology and Tourism, who are responsible for courses focusing on geography and tourism.

\footnotetext{
* Corresponding author: jaroslav.kacetl@uhk.cz
} 
This contribution aims at providing information about the way the compulsory subject called Practical English Language $1-4$ should be taught in the coming years. With respect to the overall orientation of FIM as well as current worldwide trends, information and communication technologies (ICT) are going to play an important part in teaching. As Kacetl and Frydrychova-Klimova [2] emphasized, ICT are an inseparable part of current university education. In other words, although ICT have already been used at FIM for some time, the new syllabi count on using the Internet and ICT even more frequently.

Language teachers have been using ICT for some time. In case of Practical English Language $1-4$, the most frequently used source is video from the Internet. This practice is recommended by authors like Bull and Bell [3], Muniandy and Veloo [4], all of whom suggest various websites including, among others, Discovery Education, MSN Soapbox, Next Vista for Learning, OneWorld TV, or YouTube, which is praised by Mullen and Wedwick [5] as an unfathomable well of resources. Other authors do research on and write about using video clips in education. Among others, Canning-Wilson [6] maintain that students like language classes using video in class and lists other advantages of this practice. They claim that it provides visual stimuli and contextual clues, generates prediction, helps learners to predict information and infer ideas, allows the learner to see authentic body rhythm and speech rhythm in second language discourse. McKinnon [7] divides in-class activities involving video into pre-viewing, while-viewing and postviewing tasks. Çakir [8] provides a list of techniques for using video in class, including active viewing, freeze framing and prediction, silent viewing, sound on and vision off activity, repetition and role-play, reproduction activity, dubbing activity, and follow-up activity.

The way English is taught at FIM can be labelled as Teaching English as a Foreign Language (TEFL), which is according to Griffith [9] the practice of linguistically educating those for whom English is not their native language. English is increasingly becoming the dominant medium in every domain of communication, including the tourism sector, within both local and global contexts, resulting in high demand for English speakers [10-11].

Mastering various English language skills is essential for people working in the tourism sector as it is the means for communicating with tourists and understanding cultural differences, and for increasing employees' job opportunities in this international industry [12]. English for tourism is viewed as an area of business English [13], and integrates business English and English for academic purposes by bridging workplace communication and classroom use [14]. It can be said that English for tourism deals with teaching the language needed for communication and interaction between people of different cultures in airports, tourism and travel firms, markets and hospitality (e.g. [15]). It seems that the knowledge of English should be one of the major criteria in hiring people in the tourism sector. As Ghany and Latif [16] claim, English is used as a lingua franca to communicate with international tourists in many countries. It is not surprising, therefore, that English is taught as a core subject at tourism and hospitality higher education, which applies to FIM, too.

As e.g. Prachanant [17] maintains, needs analysis plays a vital role in developing English for specific purposes curriculum. The results of Prachanant's study include the following problem areas: inability to understand foreigners' accents, inappropriate words and expressions, inadequate vocabulary, and lack of grammar knowledge. The author claims that tourism employees use English as a means to communicate, negotiate, and execute transactions with tourists. The findings showed that the majority of the tourism employees rated all four skills as highly needed. Most of them perceived speaking as the most important skill, followed by listening, reading and writing, respectively. Whereas speaking and listening are vital for face to face communication and reading is used because 
a lot of information sources are in English, writing is viewed as the least important skill by tourism employees (compare [17]).

\section{Methods}

At FIM, the language teachers agree that the students of Management of Travel and Tourism need to possess not only the four skills (speaking, listening, reading, writing) but should also be aware of the currently used specialized vocabulary applicable to their field of study and they should have a good knowledge of English grammar as both these skills are vital to their ability to communicate in the target language.

Still, the author focuses in particular on listening and speaking as tourism employees tend to consider these two skills to be the most important ones (e.g. [17]). It goes hand in hand with what Semradova and Hubackova [1], both of whom teach German at FIM, suggest, namely that in teaching the teacher must aspire to change the instructive concept of education, which leads to instant knowledge, into the communicative concept. They add that language teaching, which is clearly aimed at developing communicative competences, provides suitable conditions to make this turn.

In order to practise listening skills with the students of Management of Travel and Tourism, videos from the Internet have been used for almost ten years. As it was necessary to create worksheets for students to use before, while and after watching the video clips, a literature review of articles about using video recordings in class was employed. Another literature review looked into basic information on language teaching for travel and tourism students and employees. Then, the way of making worksheets used for practising listening and speaking was described.

The latter activity had one unexpected results. Transcripts of video recordings used in class provide material for studying the language of tourism. Collected transcripts can be used as a corpus for a subsequent frequency analysis resulting in making a list of currently used specialized vocabulary in the field of travel and tourism. Based on all the abovementioned preliminary activities, new syllabi for teaching Practical English Language $1-4$ have been made.

\section{Results}

\subsection{Video}

Video recordings from the Internet have been used in class at FIM since 2010. Video clips used in class are around four minutes long. This is because students would not pay attention to longer ones. Moreover, the video clips selected for teaching purposes are not monotonous. There are usually several different people speaking in them about a few topics, which makes the clips easier to follow. The language used in these clips is both standard and non-standard English. In fact, students can hear different "Englishes". As Crystal [18] claims, English has become a pluricentric language, which means that its norms and functions vary globally and students ought to be aware of this phenomenon. Moreover, the video clips help students improve their command of currently used English vocabulary for tourism. Therefore, all video clips selected for teaching purposes focus on travel and tourism. The most frequently used website is Deutsche Welle (DW), which contains hundreds of video clips in different languages. DW makes various series of clips, for instance Euromaxx City, presenting European cities as tourist destinations, but also shorter ones containing a limited number of parts, like Great Gardens, Holiday Challenge, 
Market Tales, or Regional Success Stories, which provide interesting information about culture, history, politics, institutions and more.

As it has been mentioned above, there are different ways how to use video in class and it should always be well-prepared. The most suitable format for Management of Travel and Tourism students is a one-page worksheet (see Fig. 1) containing the video clip title, the website, a short text introducing the topic, key vocabulary, and exercises. Teachers use a two-page version with key. As of June 2018, there are more than one hundred worksheets to their corresponding English language video clips for the students of Management of Travel and Tourism. Another outcome are two textbooks English Listening Exercises [19] and English Listening Exercises II [20] with 40 and 50 worksheets, respectively. Seventy of these worksheets are meant for the students of Management of Travel and Tourism.

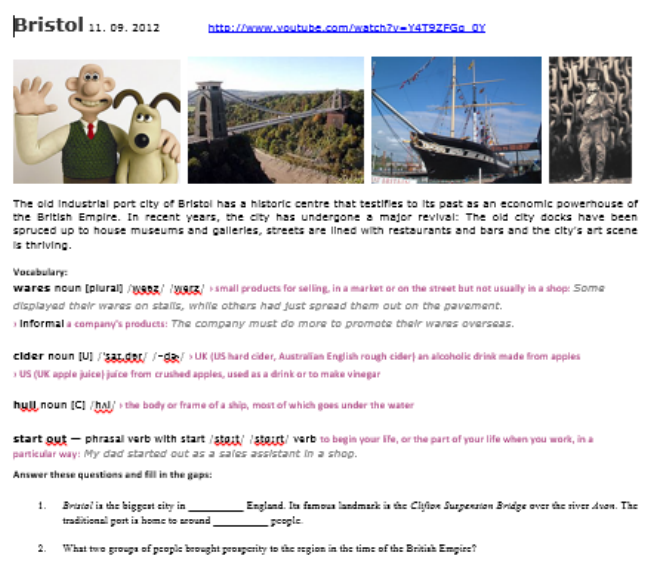

Fig. 1. The layout of listening worksheets - an example.

\subsection{Vocabulary and dictionaries}

The approach to teaching vocabulary is threefold. First, vocabulary from the course book CAE Result and selected keywords included in the above mentioned worksheets to video clips are taught in classes and then tested. Second, transcripts of tourism-related video clips were analysed by means of the corpus approach and the results have been taken into consideration in selecting vocabulary taught in classes and/or meant for self-study and testing, too. Last but not least, close cooperation between the Department of Applied Linguistics and the Department of Recreology and Tourism resulted in determining the most important areas of vocabulary the students of Management of Travel and Tourism should be able to use.

Whereas the first group of vocabulary does not need any further explanation, the latter two do. The electronic version of video clip transcripts proved to be a good source of material to be analysed by means of the British National Corpus, more specifically through a word frequency analysis done by the Sketch Engine. As Kacetl and Klimova [21] inform, as of April 2015, the studied file contained 24,177 tokens. For instance, seven broad categories of frequently used nouns were identified: places (and place names), time, architecture, people, culture, food and drink, numbers. Consequently, the corresponding vocabulary is taught. First, geographical names, their spelling, pronunciation and the usage of the definite article are taught. Similarly, teachers also focus on the correct usage of time expressions, words related to architectural styles and their most significant features, or vocabulary categorised by arts (painting, sculpting, or music). Gastronomy is another broad 
area of lexical interest in the field of tourism. Last but not least, correct saying numbers is important, too (compare [21]).

So far, there have been created several short dictionaries (or lists of selected vocabulary), which are divided as follows: trees and bushes, flowers and plants, animals, fish, architecture, or culture. For teaching and learning purposes, all these dictionaries are bilingual. Nonetheless, picture dictionaries are sometimes used, too. The extent of compulsory vocabulary depends on the actual level of students who attend the class in question and common knowledge of the population of the Czech Republic.

\subsection{Speaking}

Once again, with respect to the content of various textbook for English in travel and tourism and in cooperation with the Department of Recreology and Tourism, twelve topic areas were identified as significant in relation to teaching English for the students of Management of Travel and Tourism. These topics were divided into four groups of three as there are four semesters for teaching them. The selected topics are as follows: Social Media in Tourism, Reasons for Travel, Trends in Tourism; Means of Transport - land, Means of Transport - air and water, Accommodation Facilities; Cultural Heritage (attractions and events), Natural Heritage, Gastronomy; Jobs in Tourism, Marketing in Tourism, Geographical Terms.

Means of Transport - land

1. What means of transport are depicted in the pictures below?

2. Which of these means of transport do you like most and why?

3. Which of the scenes is the closest to your ideal way of travelling?
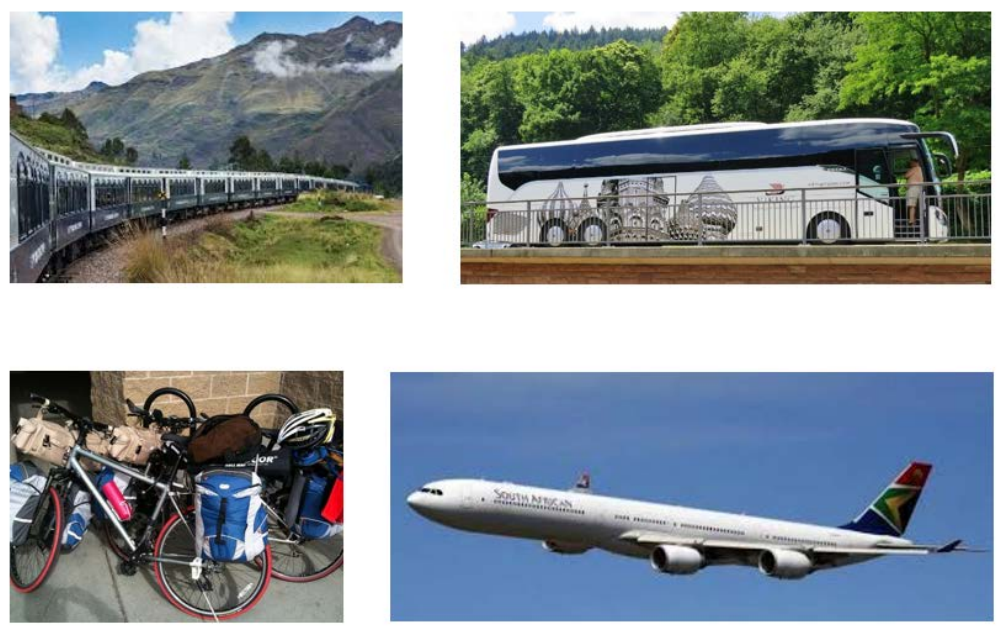

Fig. 2. The layout of speaking worksheets - an example.

These topics for speaking are practised in a way similar to the collaborative task of either First Certificate in English (FCE) or Certificate in Advanced English (CAE) speaking examination. There are worksheets (see Fig. 2) with several questions and visual materials. Students work in pair and are should interact only with each other for several minutes, usually three to five. 


\subsection{Grammar}

As for grammar, Practical English Language 1and Practical English Language 2, which are taught in the first year, focus on revising and consolidation of intermediate grammar. On the other hand, grammar taught in Practical English Language 3 and Practical English Language 4, which are studied by second-year students of Management of Travel and Tourism, is much more demanding.

The list of English grammar areas in Practical English Language 3 include: review of tenses, participle clauses, relative clauses, conditionals, wishes, gerunds or infinitives (verb patterns), modal auxiliary verbs, passive voice, distancing the facts (seem/appear), inversions (emphasis), avoiding repetition. The areas causing problems to students are particularly inversions and distancing the fact.

Practical English Language 4 contains the following English grammar areas: prepositions, real and unreal tense usage, collocations and similes (adverb collocations, intensifying adverbs), linking devices, discourse markers, conjunctions, articles (geographical expressions), adjectives - order, phrasal verbs, British English versus American English. Among these areas, there are more problematic issues like order of adjectives, articles, linking devices and discourse markers.

\subsection{Syllabi}

The new syllabi for Practical English Language $1-4$ are primarily based on the course book CAE Result [21]. The whole textbook consist of 12 units. Consequently, three units are taught during each semester. The course book material is supplemented with additional materials created by teachers (see Fig. 1 and Fig. 2).

Each unit is taught in three ninety-minute long classes. Speaking exercises focused on selected topics are done in once in three classes. Listening exercises based on selected videos are done in every single class as well as grammar, the latter only in case of Practical English Language $3-4$ courses. Practical English Language $1-2$ courses contain intermediate grammar, which does not need such a thorough practice. Of course, there is a lack of time to do the grammar in detail. Students are therefore advised to self-study additional grammar exercises based on explanations, instructions and examples given in class.

\section{Conclusion}

Video clips (listening) as well as speaking exercises are done in more or less all classes, advanced grammar is taught in Practical English Language $3-4$ courses. Dictionaries with specialised vocabulary are based on listening exercises and materials recommended by the Department of Recreology and Tourism. Some vocabulary is meant for self-study. All courses should be supported by corresponding e-learning courses, which will be created in the coming months.

The most significant outcomes achieved, based on the need to focus language classes on topics for state examinations from Management of Travel and Tourism, include the fact that there were identified ways of adjusting suitable and up-to-date material from the Internet, and the most frequently used vocabulary. Furthermore, as the students of Management of Travel and Tourism may undergo practical training in a geopark or national park, they ought to be aware of basic vocabulary linked to topics like geology, botany, or zoology, too. All in all, the most important skills to be worked on are listening, speaking and vocabulary. As it can be expected, all of these with special attention to the field of travel and tourism. Last but not least, advanced grammar should be taught, too. The reason being 
that it is desirable for most tourism employees to master the English language at the best possible level.

This article is supported by the Internal Grant Project of the Faculty of Informatics and Management, University of Hradec Kralove ID: 1903.

\section{References}

1. I. Semradova, S. Hubackova. Characteristics of Language Teaching for Travel and Tourism Management Students at the Faculty of Informatics and Management. Procedia - Social and Behavioral Sciences. 93, 665-669 (2013) [online] Available at: $<$ https://www.sciencedirect.com/science/article/pii/S1877042813033612> [Accessed 25 June 2018].

2. J. Kacetl, B. Frydrychova-Klimova. English Vocabulary in Video Clips on Travel and Tourism. Procedia Social and Behavioral Sciences, 182, 364-368 (2015)

3. L. Bell, G. Bull. Digital video and teaching. Contemporary Issues in Technology and Teacher Education, 10(1) (2010) [online] Available at: $<$ http://www.citejournal.org/vol10/iss1/editorial/article1.cfm $>$ [Accessed 5 April 2014].

4. B. Muniandy, S. Veloo. Managing and Utilizing Online Video Clips for Teaching English Language: Views of TESOL Pre Service Teachers. 2nd International Conference on Education and Management Technology, IPEDR, 13, 173-178 (2011) [online] Available at: <http://www.ipedr.net/vol13/34-T00063.pdf> [Accessed 7 January 2012].

5. R. Mullen, L. Wedwick. Avoiding the Digital Abyss: Getting Started in the Classroom with YouTube, Digital Stories and Blogs, 82(2), 66-69 (2008) [online] Available at: $<$ http://www.academia.edu/930232/Avoiding_the_digital_abyss_Getting_started_in_th e_classroom_with_YouTube_digital_stories_and_blogs $>$ [Accessed 5 April 2014].

6. C. Canning-Wilson. Practical Aspects of Using Video in the Foreign Language Classroom, The Internet TESL Journal, VI, No. 11 (2000) [online] Available at: $<$ http://iteslj.org/Articles/Canning-Video.html > [Accessed 5 April 2014].

7. M. McKinnon. Teaching technologies: teaching English using video, (2011?) [online] Available at: <http://www.onestopenglish.com/support/methodology/teachingtechnologies/teaching-technologies-teaching-english-using-video/146527.article> [Accessed 6 April 2014].

8. İ. Çakir. The Use of Video as an Audio-Visual Material in Foreign Language Teaching Classroom, The Turkish Online Journal of Educational Technology - TOJET October 2006 ISSN: 1303-6521 5, Issue 4 Article 9 (2006) [online] Available at: $<$ http://www.tojet.net/articles/v5i4/549.pdf> [Accessed 5 April 2014].

9. S. Griffith. Teaching English abroad: Talk your way around the world (13th ed.). Oxford: Vacation Work (2014)

10. A. Khamkhien. Teaching English Speaking and English Speaking Tests in the Thai Context: A Reflection from Thai Perspective. English Language Teaching Journal, 3(1), 184-200 (2010) [online] Available at: $<$ http://www.ccsenet.org/journal/index.php/elt/article/view/5253> [Accessed 25 June 2018].

11. P. Punthumasen. International Program for Teacher Education: An Approach to Tackling Problems of English Education in Thailand. (2007) [online] Available at: 
$<$ http://backoffice.onec.go.th/uploaded/Category/EngBook/ProblemEngEd13dec07-0303-2011.pdf $>$ [Accessed 25 June 2018].

12. D. Leslie, H. Russell. The importance of foreign language skills in the tourism sector: A comparative study of student perceptions in the UK and continental Europe. Tourism Management 27 1397-1407 (2006). [online] Available at: $<$ http://isiarticles.com/bundles/Article/pre/pdf/21038.pdf $>$ [Accessed 25 June 2018].

13. B. Cho. Usefulness and Enjoyment of Simulation Activities for Tourism Major Students, Modern English Education, 6(1), 3-17 (2005) [online] Available at: $<$ http://210.101.116.28/W_files/kiss61/1f100038_pv.pdf $>$ [Accessed 25 June 2018].

14. A. C. Fuentes. The use of corpora and IT in evaluating oral task competence for tourism English, CALICO Journal, 22(1), 5-24 (2004)

15. K. Afzali, M. Fakharzadeh. A needs analysis survey: The case of tourism letter writing in Iran, ESP World, 8, Issue 1 (22), (2009) [online] Available at: <http://www.espworld.info. http://www.espworld.info/Articles_22/PDF/A\%20needs\%20analysis\%20survey.pdf> [Accessed 25 June 2018].

16. S. Y. A. Ghany, M. M. A. Latif. English language preparation of tourism and hospitality undergraduates in Egypt: Does it meet their future workplace requirements? Journal of Hospitality, Leisure, Sport \& Tourism Education 11, 93-100 (2012) [online] Available at: $<$ http://daneshyari.com/article/preview/1011330.pdf $>$ [Accessed 25 June 2018].

17. N. Prachanant. Needs Analysis on English Language Use in Tourism Industry. Procedia - Social and Behavioral Sciences 66, 117-125 (2012) [online] Available at: $<$ https://ac.els-cdn.com/S187704281205238X/1-s2.0-S187704281205238Xmain.pdf?_tid=73aa1 fd9-66e 0-40aa-b1851aac6f96e09c\&acdnat=1529923226_9b9e263cd0316f863e711bbe5b52a0fb> [Accessed 25 June 2018].

18. D. Crystal, The Stories of English. Overlook Press (2004)

19. J. Kacetl. English Listening Exercises. Hradec Králové: Gaudeamus (2011)

20. J. Kacetl. English Listening Exercises II. Hradec Králové: Gaudeamus (2014)

21. J. Kacetl, B. Klimova. English Vocabulary for Tourism - A Corpus-Based Approach. In: Christiansen H., Stojanovic I., Papadopoulos G. (eds) Modeling and Using Context. CONTEXT 2015. Lecture Notes in Computer Science, 9405. Springer, Cham (2015)

22. K. Gude, M. Stephens. CAE Result. Oxford (2008) 